\title{
Infection Dynamics of Helminth Parasites in the Silver Carp, Hypophthalmichthys molitrix with Reference to Season
}

\author{
G. P. Thakur*, A. N. Jha and B. S. Jha \\ Department of Zoology, L.N. Mithila University, Darbhanga- 846008, India \\ *Corresponding author
}

\section{A B S T R A C T}

\begin{tabular}{l} 
K e y w o r d s \\
$\begin{array}{l}\text { Helminth parasites, } \\
\text { Seasonal variations, } \\
\text { Silver carp }\end{array}$ \\
\hline Article Info \\
\hline $\begin{array}{l}\text { Accepted: } \\
\text { 26 May 2020 } \\
\text { Available Online: } \\
\text { 10 June 2020 }\end{array}$ \\
\hline
\end{tabular}

The present study, carried out from September 2018 to August 2019, reports the seasonal fluctuations in the intensity of infection level of helminth parasites in the silver carp, Hypophthalmichthys molitrix, reared along with native carps in ponds and other water bodies of Darbhanga , Bihar, India. The host fish were found to parasitize two monogenean ecto-parasites, Dactylogyrus vastator (in gill \& skin) and Gyrodactylus elegans (in skin); one cestode (Bothriocephalus acheilognathi in intestine) and one nematode (Camallanus ophiocephali in stomach). These parasites revealed seasonal fluctuations in their prevalence percentage, mean intensity and abundance. The overall highest prevalence and abundance were of Dactylogyrus (54\% and 0.064 ) followed by Gyrodactylus (5\% and 0.06) Bothriocephalus (3.9\% and 0.05) and Camallanus (3.3\% and 0.05). However, the mean intensity was highest for Camallanus (1.5) and lowest (1.18) for Dactylogyrus. The highest prevalence and abundance of the parasites were recorded during summer (June-Aug) followed by spring (Mar-May) and autumn (Sept-Nov) and lowest in winter (Dec-Feb) seasons. The winter months did not show infection of any parasites except Dactylogyrus which was also minimal. The observed seasonal fluctuations have been attributed to physico-chemical parameters, especially temperature, feeding habits and lifecycle patterns of the parasites.

\section{Introduction}

Fishery sector has received due attention of the Govt. and scientific communities during the past few decades in our country. This sector besides providing cheap source of protein has become a source of livelihood for some 14 million people of socioeconomically backward sections and has substantial contribution to the national economy by earning revenue in foreign exchange through export. The efforts taken by the stakeholders of this sector have increased fish production manifold from just 0.75 million tonnes in
1950-51 to 9.04 million tonnes in 2012-13 (Baruah et al., 2015) and 13.7 million tonnes in 2018-19 (The Economic Times, July, 04, 2019). Though a target of 20 million tonnes of fish production by the year 2022 has been set by the Govt. of India (Union Budget, 202021 ), yet this will leave a major gap when compared to growing fish demand.

Even this set target seems very difficult to achieve due to various natural and other constraints faced by this sector. One such important factor is the parasitic infections in fishes which deteriorates their food value and 
hampers growth leading to less productivity. Helminths are one of the major groups of parasites in fish causing severe loss in their productivity (Jha et al., 1992, Sobecka and Slominska, 2007; Thakur et al., 2019).

In consideration of the above facts, the present study was undertaken which reports the seasonal variation in the intensity of infestation of helminth parasites in the silver carp, Hypophthalmichthys molitrix, which is now well established in India and used in polyculture along with native major carps Catla, Rohu and Mrigal.

\section{Materials and Methods}

Specimens of the silver carp, Hypophthalmichthys molitrix, were collected fortnightly over a period of one year (September, 2018 to August, 2019) from the local fishermen to whom the regional ponds and other water bodies have been leased out by the Govt. of Bihar. Altogether 180 fishes (size ranging between $22 \mathrm{~cm}-27 \mathrm{~cm}$ ) were collected in one calendar year. Fish were brought to the laboratory in ice-box and then refrigerated.

These were examined for helminth parasites infection in skin, gill, stomach and intestine within 2-3 days following the procedure of Mofasshalin et al., (2012). After identification (Yamaguti, 1958, 1963), the parasites were preserved in AFA (120 ml distilled water +6 $\mathrm{ml}$ ethyl alcohol $+30 \mathrm{ml}$ formalin $+10 \mathrm{ml}$ glycerin $+0.5 \%$ neutral or methyl blue or acetocarmine) solution for detailed investigation.

Season-wise average prevalence, abundance and mean intensity was determined by following formulae (Margolis et al., 1982).

Prevalance $=\frac{\text { Total no. of host fish infected }}{\text { Total no. of host fish examined }} \times 100$
Mean Intensity $=\frac{\text { Total no. of Parasites collected }}{\text { Total no. of infected host examined }}$
Abundance or Relative density $=\frac{\text { Total no. of Parasites collected }}{\text { Total no. of infected host examined }}$

\section{Results and Discussion}

The results of the present study have been elaborated in Table 1 and 2. Altogether four parasites were identified during this study, of which two (Dactylogyrus vastator and Gyrodactylus elegans) were monogeneans, one (Bothriocephalus acheilognathi) cestode and one (Camallanus ophiocephali) was a nematode. Dactylogyrus, collected from gill \& skin and Gyrodactylus, collected from skin, are the two ecto-parasites whereas Bothriocephalus and Camallanus are the endoparasites isolated from intestine and stomach respectively. On annual basis, the overall prevalence $(54.4 \%)$ and abundance (0.64) were recorded for Dactylogyrus followed by Gyrodactylus (5\% and 0.06), Bothriocephalus $(3.9 \%$ and 0.05$)$ and Camallanus (3.3\% and 0.05) respectively. As regards mean intensity, it was highest for Camallanus (1.5) and lowest for Dactylogyrus (1.18) with intermediate value of 1.42 and 1.33 for Bothriocephalus and Gyrodactylus (Table 1).

The seasonal fluctuations in intensity of infestation of these parasites in terms of prevalence (\%), mean intensity and abundance have been shown in Table 2. The seasonal fluctuation in the infection level of all the four parasites revealed interesting results. The maximum prevalence and abundance of the parasites were recorded in summer followed by spring, autumn and winter months. The highest prevalence and abundance was recorded for Dactylogyrus (73.33\% and 0.9) in summer months followed by spring (59\% and 0.68$)$, autumn $(47.5 \%$ and $0.52)$ and winter $(25.0 \%$ and 0.3$)$ and lowest 
for Camallanus. Interestingly, during winter months (Dec-Feb) one ecto-parasite (Gyrodactylus) and both the endo-parasites (Camallanus and Bothriocephalus) were absent and as such could not be isolated / collected. Besides, heavily infected fish showed whitish to yellowish cysts in skin and gill as well as excessive secretion of mucus and slight haemorrhage at the base of fins.

\section{Discussion}

The findings of this study closely conform with those of some earlier reports (Pojmanska and Chabros, 1993, Ozan et al., 2008, Shamsi et al., 2009; Vijyaysundardeva et al., 2018). Our results reveal that the major parasite of the host fish $H$. molitrix is Dactylogyrus vastator which was maximum in summer and spring with occurrence throughout the year in all seasons.

The prevalence of Gyrodactylus was second to Dactylogyrus followed by Bothriocephalus and Camallanus, however, the host fishes were observed to be free from these three parasites during winter a month (Dec $-\mathrm{Feb})$ which suggests their consumption most preferably during this season. The observed seasonal fluctuations in the level of infection of these parasites may be attributed to abiotic factors as well as high contamination of the water bodies inhabiting the fish leading to impaired metabolic activity and suppression of immune system of the host fish.

Mofasshalin et al., (2012) have also associated infection and infestation rate of parasites with stocking density, water depth, temperature and other physico-chemical parameters along with ill management of water bodies. Some earlier reports also correlate occurrence and intensity of infestation of helminth parasites with $\mathrm{pH}$, temperature, oxygen content, salinity and eutrophication (Marcogliese, 2001; Modu et al., 2011). The peak of infection of Dactylogyrus during summer months and decline to the minimum in winter season coincides with fall of water temperature and is in conformity with previous studies denoting seasonal fluctuation of Dactylogyrus to be influenced by temperature, that oxygen concentration and free $\mathrm{CO}_{2}$ level of water (Pojmanskaya and Chabros, 1993).

Further, the life cycle of both Dactylogyrus and Gyrodactylus is direct with no intermediate host and both being thermophilic parasites with a shorter life cycle may also be a possible explanation for the dominance of both the genera of parasites during summer months (Pojmanskaya, 1995).

The observed higher population of Dactylogyrus may be a matter of concern for fish production since these cause high mortality of fry and fingerlings leading to low productivity of fish (Shamsi et al., 2009).

The observed absences of Gyrodactylus, Camallanus and Bothriocephalus during winter and higher occurrence during summer seasons have direct correlation with temperature.

The eggs of these parasite is sensitive to low temperature and even die within 2-3 hours of exposure to very low temperature and when the temperature rises above $25-26^{\circ} \mathrm{C}$, its coracidium larvae develop from eggs which are ingested by their intermediate hosts (several species of copepods) where the procercoid stage of parasite develops and the fish gets infected by consuming the intermediate host (Kir and Tekin-Ozan, 2007).

These may be cited as one of the major reasons behind higher occurrence of both these parasites in summer and lowest to nil during autumn/winter months. 
Table.1 Overall prevalence of helminth parasites in the silver carp, Hypophthalmichthys molitrix

\begin{tabular}{|l|l|l|l|l|l|l|}
\hline $\begin{array}{l}\text { No of Host } \\
\text { Fish } \\
\text { Examined }\end{array}$ & $\begin{array}{l}\text { No. of Host } \\
\text { infected with type } \\
\text { of parasite }\end{array}$ & $\begin{array}{l}\text { Site of } \\
\text { Infection }\end{array}$ & $\begin{array}{l}\text { No. of } \\
\text { parasites } \\
\text { collected }\end{array}$ & $\begin{array}{l}\text { Prevalence } \\
\text { \% }\end{array}$ & $\begin{array}{l}\text { Mean } \\
\text { Intensity }\end{array}$ & Abundance \\
\hline $\mathbf{1 8 0}$ & $\begin{array}{l}\text { Dactylogyrus } \\
\text { vastator-98 } \\
\text { (Monogenea) }\end{array}$ & Gill, Skin & 116 & 54.4 & 1.18 & 0.64 \\
\hline $\mathbf{1 8 0}$ & $\begin{array}{l}\text { Gyrodactylus } \\
\text { elegans-09 } \\
\text { (Monogenea) }\end{array}$ & Skin & 12 & 5.0 & 1.33 & 0.06 \\
\hline $\mathbf{1 8 0}$ & $\begin{array}{l}\text { Camallanus } \\
\text { ophiocephali-06 } \\
\text { (Nematode) }\end{array}$ & Stomach & 09 & 3.3 & 1.5 & 0.05 \\
\hline $\mathbf{1 8 0}$ & $\begin{array}{l}\text { Bothriocephalus } \\
\text { acheilognathi-07 } \\
\text { (Cestode) }\end{array}$ & Intestine & 10 & 3.9 & 1.42 & 0.05 \\
\hline
\end{tabular}

Table.2 Infection dynamics of helminth parasites in the silver carp with reference to season

\begin{tabular}{|c|c|c|c|c|c|c|}
\hline Season & $\begin{array}{l}\text { No.of Host } \\
\text { fish } \\
\text { examined }\end{array}$ & $\begin{array}{l}\text { No. of } \\
\text { Infected } \\
\text { fish }\end{array}$ & $\begin{array}{l}\text { Parasites (Site of infection and } \\
\text { No. collected) }\end{array}$ & $\begin{array}{l}\text { Prevalence } \\
\%\end{array}$ & $\begin{array}{l}\text { Mean } \\
\text { Intensity }\end{array}$ & Abundance \\
\hline $\begin{array}{l}\text { Autumn } \\
\text { (Sept- Nov) }\end{array}$ & 40 & $\begin{array}{l}19 \\
02 \\
01 \\
01\end{array}$ & 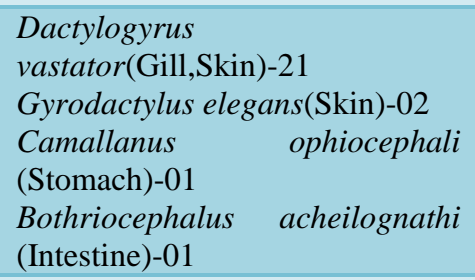 & $\begin{array}{l}47.5 \\
5.0 \\
2.5 \\
2.5\end{array}$ & $\begin{array}{l}1.10 \\
1.0 \\
1.0 \\
1.0\end{array}$ & $\begin{array}{l}0.52 \\
0.05 \\
0.025 \\
0.025\end{array}$ \\
\hline $\begin{array}{l}\text { Winter } \\
\text { (Dec-Feb) }\end{array}$ & 36 & $\begin{array}{l}09 \\
\text { Nil } \\
\text { Nil } \\
\text { Nil }\end{array}$ & $\begin{array}{l}\text { Dactylogyrus vastator } \\
\text { (Gill, Skin)-11 } \\
\text { Gyrodactylus elegans (Skin)-Nil } \\
\text { Camallanus ophiocephali } \\
\text { (Stomach)-Nil } \\
\text { Bothriocephalus acheilognathi } \\
\text { (Intestine)-Nil }\end{array}$ & $\begin{array}{l}25.0 \\
- \\
- \\
-\end{array}$ & $\begin{array}{l}1.22 \\
- \\
- \\
-\end{array}$ & $\begin{array}{l}0.30 \\
- \\
- \\
-\end{array}$ \\
\hline $\begin{array}{l}\text { Spring } \\
\text { (Mar- May) }\end{array}$ & 44 & $\begin{array}{l}26 \\
02 \\
02 \\
02\end{array}$ & $\begin{array}{l}\text { Dactylogyrus vastator } \\
\text { (Gill, Skin)-30 } \\
\text { Gyrodactylus elegans (Skin)-02 } \\
\text { Camallanus } \quad \text { ophiocephali } \\
\text { (Stomach)-02 } \\
\begin{array}{l}\text { Bothriocephalus } \\
\text { (Intestine)-03 acheilognati }\end{array}\end{array}$ & $\begin{array}{l}59.09 \\
4.54 \\
4.54 \\
4.54\end{array}$ & $\begin{array}{l}1.15 \\
1.0 \\
1.0 \\
1.5\end{array}$ & $\begin{array}{l}0.68 \\
0.04 \\
0.04 \\
0.06\end{array}$ \\
\hline $\begin{array}{l}\text { Summer } \\
\text { (June-Aug) }\end{array}$ & 60 & $\begin{array}{l}44 \\
05 \\
03 \\
04\end{array}$ & $\begin{array}{l}\text { Dactylogyrus vastator } \\
\text { (Gill, Skin)-54 } \\
\text { Gyrodactylus elegans (Skin)-08 } \\
\text { Camallanus } \quad \text { ophiocephali } \\
\text { (Stomach)-05 } \\
\text { Bothriocephalus acheilognathi } \\
\text { (Intestine)-06 }\end{array}$ & $\begin{array}{l}73.33 \\
8.33 \\
5.0 \\
6.66\end{array}$ & $\begin{array}{l}1.22 \\
1.6 \\
1.66 \\
1.5\end{array}$ & $\begin{array}{l}0.9 \\
0.13 \\
0.08 \\
0.1\end{array}$ \\
\hline
\end{tabular}

This study concludes that water bodies of Darbhanga region (present area of study) need proper management particularly during summer which are peak months of helminth parasites infection causing heavy mortality to fish fry and fingerlings leading to their less 
production and that most favoured periods for consumption of the fish $H$. molitrix by human beings are the winter months (Dec to Feb.) when, save and except very low degree of infection by Dactylogyrus, the fish were free from all other parasites.

\section{Acknowledgments}

The first author extends his thanks to Dr. B. S. Jha, Professor and Head, Department of Zoology, L. N. Mithila University, Darbhanga for providing laboratory facilities and for his constant encouragement and critical suggestions.

\section{References}

Baruah, D., Talukdar, U. and Talukdar, K.C. (2015). Emerging trends and structural transformation of Fishery sector: The case of Assam. Economic Affairs. 60(3): 487-493.

Jha, A.N., Sinha, P. and Mishra, T.N.(1992). Seasonal occurrence of helminth parasites in fishes of Sikandarpur reservoir, Muzaffarpur (Bihar). Indian Journal of Helminthology. 44:1-8.

Kir, I. and Tekin-Ozan, S, (2007). Helminth infections in common carp, Cyprinus carpio L. 1758 (Cyprinidae) from Kovada lake (Turkey). Turkiye Parasitology Derg. 31:232-236.

Marcogliese, D.J. (2001). Implications of climate change for parasitism of animals in the aquatic environment. Canadian Journal of Zoology.79:13311352.

Margolis, L., Esch, G.W., Holmes, J.C., Kuris, A.M, and Schad, G.A. (1982). The use of ecological terms in parasitology (Report of an adhoc committee of the American Society of parasitologists). J. Parasitol. 68:131133.

Modu, B.M., Saiful, M., Kartini, M., Kassim,
Z., Hassan. M. and Shaharom- Harrison, F.M. (2011). Impact of monogenean parasite in relation to water quality effects on the Structural changes in the gills of freshwater cat fish, Hemibagarus nemurus valenciennes 1840. Empowering Science, Technology and Innovation towards a better tomorrow better tomorrow. UMTAS LS017, 2011.

Mofasshalin, M.S., Bashar, M.A., Alam, M.M., Alam, G.M., Moumita, D., Mazlan, A.G. and Simon. K.D. (2012). Parasites of three Indian minor carps of Rajshahi, Bangladesh Asian Journal of Animal and Veterinary Advances. 7:613-620.

Pojmanskaya, T. (1995). Seasonal dynamics of occurrence of some parasites in four cyprinid fish cultured in ponds, II. Monogenea. Acta Parasitologica. 40:7984.

Pojmanskaya, T. and Chabros, M. (1993). Parasites of common carp and three introduced cyprinid fish in pond culture. Acta Parsitological. 38: 101-108.

Shamsi, S., Jalali and Meshgi, A.M. (2009). Infection with Dactylogyrus spp. among introduced cyprinid fishes and their geographical distribution in Iran Iranian Journal of Veterinary Research. 10:7074.

Sobecka, E. and Slominska, M. (2007). Species richness, diversity and specificity of the parasites of bream Abramis brama (L.) and perch Perca fluviatilis L. in the estuary of the Odra river, Poland. Helminthologia. 44:188192.

Tekin-Ozan, S., Kir, I and Barlas, M. (2008). Helminth parasites of common carp (Cyprinus carpio L., 1758) in Beysehir lake and population dynamics related to month and host size. Turkish Journal of Fisheries and Aquatic Sciences. 8:201205. 
Thakur, G .P., Jha, A.N. and Jha, B.S. (2019). Seasonal variation in the infestation of helminth parasites in the common carp, Cyprinus carpio. Biojournal. 14:41-46. Vijaysundardeva, G., Dash, G., Ramudu, K.R. and Abraham, T.J. (2018). Prevalence of parasitic disease of Indian major carps in selected districts of West Bengal, India. Int. J. Curr. Microbiol. App. Sci. 7: 2784-
2805.

Yamaguti, S. (1958). Systema Helminthum Vol. 1. The Digenetic trematodes of vertebrates, Pt I \& II. Interscience, Publisher, Inc., New York.

Yamaguti, S. (1963). Systema Helminthum Monogenea and Aspidocotylea. Vol.4. Intersciences, Publisher, Inc., New York, London.

\section{How to cite this article:}

Thakur, G. P., A. N. Jha and Jha, B. S. 2020. Infection Dynamics of Helminth Parasites in the Silver Carp, Hypophthalmichthys molitrix with Reference to Season. Int.J.Curr.Microbiol.App.Sci. 9(06): 3781-3786. doi: https://doi.org/10.20546/ijcmas.2020.906.448 